\title{
Extracts from physalis leaves (Physalis peruviana L.) for prospective application in medicine and cosmetics
}

\section{Tanya Ivanova ${ }^{1}$, Venelina Popova ${ }^{1}$, Nadezhda Mazova ${ }^{1}$, Albena Stoyanova ${ }^{1}$, Stanka Damyanova ${ }^{2}$}

\author{
1 - University of Food Technologies, Plovdiv, Bulgaria \\ 2 - University of Russe, Branch Razgrad, Bulgaria
}

Keywords:

Physalis

Extracts

Polyphenols

Flavonoids

Triterpenes

Article history:

Received

06.09.2018

Received in revised

form 28.10.2018

Accepted

28.03.2019

\section{Corresponding}

author:

Venelina Popova

E-mail:

vpopova2000@

abv.bg

\section{DOI:}

$10.24263 / 2304-$

974X-2019-8-1-5

\section{Abstract}

Introduction. The aim of research is to characterize the chemical composition of physalis leaves and the obtaining of extracts rich in bioactive compounds intended for medical and cosmetic applications.

Materials and methods. Extraction of dried physalis leaves was carried out under the following conditions: hydromodule $-1: 10$ $(\mathrm{w} / \mathrm{v})$, solvents $-95,70,50$ and $30 \mathrm{vol} . \%$ ethanol, temperature -20 , 40 and $60^{\circ} \mathrm{C}$, and duration $-1,3$ and $5 \mathrm{~h}$. The content of polyphenols, flavonoids and triterpenes in the leaves and in the obtained extracts was determined by HPLC.

Results and discussion. The analyzed physalis leaves from variety Plovdiv and from the bio-farm were with $8.32 \%$ and $8.79 \%$ moisture, respectively. The plant materials contained $9.62 \%$ and $10.58 \%$ tannins, respectively. Extract color varied by solvent concentration: yellow-orange (with $30 \%$ ethanol), yellow-brown $(50 \%$ ethanol), green-brown $(70 \%$ ethanol), and brown $(95 \%$ ethanol). The experimental data and the derived equations showed that the two main factors - temperature and duration, had a strong influence on the content of extracted tannins. The optimal conditions of the process were: 5 -hour extraction at a temperature of $60^{\circ} \mathrm{C}$, with 30 and $50 \%$ ethanol for the leaves from Plovdiv genotype, and with 50 and $70 \%$ ethanol - for the bio-farm genotype. Twelve phenolic acids were identified in the leaves and extracts from Plovdiv genotype and 10 - in those from the bio-farm genotype. Rutin was the dominant flavonoid in the leaves and extracts from both genotypes. The major triterpene in the leaves and in the extracts was oleanolic acid, followed by betulin.

The extracts from physalis leaves are rich in bioactive substances (phenolic acids, flavonoids and triterpenes), and have the prospective for possible application in medicinal and cosmetic products.

Conclusions. This study provides for the first time data about the optimal conditions for the extraction of Physalis peruviana leaves, as well as information about the content of certain biologically active components in the leaves and in the obtained extracts. These are the first results reported about physalis genotypes grown in Bulgaria. 


\section{Introduction}

The genus Physalis (family Solanaceae) comprises nearly 120 wild and cultivated species common to many countries around the world [1]. Among them, the most widely distributed and commercially important is Physalis peruviana L. [2], also known as Cape gooseberry, goldenberry, Inca berry, or simply physalis. The edible part of the plant is the fruit - ovoid in shape, cherry-sized, yellow-to-orange-fleshed and juicy. It is described as tomato-like in flavor and appearance, though the taste (sweet and sour) is much richer with a hint of tropical luxuriance [3]. The fruit is hidden in an inflated calyx or fruit basket, protecting it from insects, birds, diseases and harsh climate conditions [2, 3].

While physalis fruit, along with many other subtropical berries [4], has been long acknowledged as a source of valuable bioactive and nutritional substances, there is scarce data about the chemical composition of physalis leaves or leaf-derived bioactive products.

In a study by Ertürk et al. [5], the total phenolic and flavonoid content of an ethanol extract from physalis leaves were estimated to $1.368 \mathrm{mg} \mathrm{GA} / \mathrm{g}$ and $0.635 \mathrm{mg} \mathrm{QE} / \mathrm{g}$, respectively. Wu et. al. [6] obtained ethanolic, aqueous and supercritical $\mathrm{CO}_{2}$ extracts from physalis leaves. Total flavonoid and phenol contents were $37.39 \mathrm{mg} / \mathrm{g}$ and $18.57 \mathrm{mg} / \mathrm{g}$, respectively, in the aqueous extract, and $94.97 \mathrm{mg} / \mathrm{g}$ and $85.81 \mathrm{mg} / \mathrm{g}$ - in the ethanolic extract. The presence of phytochemicals with different biological activities (alkaloids, saponins, tannins, steroids, terpenoids, and flavonoids) was detected in aqueous extracts from physalis leaves, although it was not quantified [7]. Cirigliano et al. [8] studied crude physalis extracts and the data indicated that the extract and its two major withanolides (withanolide $\mathrm{E}$ and 4$\beta$-hydroxy withanolide E) could be used to develop baits to control the fruit fly Ceratitis capitata. An extract of physalis leaves showed antibiotic activity against Gram-positive bacteria from genus Staphylococcus [9].

In folk medicine, the juice of physalis leaves has been used in the treatment of worm and bowel complaints, while heated leaves are applied as a poultice $[1,10,20]$.

Although physalis is not a popular crop in Bulgaria, an original local variety of $P$. peruviana named Plovdiv has been selected and officially recognized by the national authorities in 2006 [11].

The above-presented brief review on available data clearly identifies the lack of sufficient scientific evidence about the chemical composition of physalis leaves and about the obtaining of extracts rich in bioactive compounds intended for medical and cosmetic applications, which is set as the objective of current study.

\section{Materials and methods}

\section{Plant Material}

Leaves of two genotypes of cultivated phyisalis (Physalis peruviana L.) were investigated. The first genotype was the only local Bulgarian variety of physalis named Plovdiv and was grown in the region of Plovdiv city, located in Central South Bulgaria [11]. The second genotype was grown and provided by a certified bio-farm (Versol Ltd.), located in Lik village, North-West Bulgaria. Fresh leaves were picked in the period SeptemberOctober, and then were air-dried in the shade. Dried leaves were isolated in plastic bags and stored at a temperature of $5-8^{\circ} \mathrm{C}$ until processing.

\section{Chemicals}

HPLC grade methanol and acetonitrile, as well as phenolic acid and flavonoid standards were purchased by Sigma (Sigma-Aldrich Chemie GmbH, Germany). 


\section{Chemical analyses}

The moisture content of the leaves was determined by drying $\left(\right.$ at $105^{\circ} \mathrm{C}$ ) to constant weight [12], and all data in the study were calculated on a DW basis. The content of tannins was determined by titration of hot water extract with potassium permanganate solution using indigo carmine as indicator [12]. The HPLC analysis of polyphenols, flavonoids and triterpenes in the plant material and in the extracts was according to Marchev et al. [13, 14].

\section{Obtaining of extracts}

Extraction was carried out in laboratory conditions, in a batch static mode, at a ratio of raw material to solvent $=1: 10(\mathrm{w} / \mathrm{v})$. Four solvents were used for the extraction, representing different ethanol concentrations: $95,70,50$ and $30 \mathrm{vol} . \%$. The solvent, its concentrations and the hydromodule were chosen on the basis of authors' own published data. The influence of the technological factors - temperature and duration of extraction, was examined by mathematical modeling of the experiment (Table 1).

Table 1

Mathematical modeling of the experiment

\begin{tabular}{|c|c|c|}
\hline Variant & Duration, $\left(\mathbf{x}_{\mathbf{1}}\right), \mathbf{h}$ & Temperature, $\left(\mathbf{x}_{\mathbf{2}}\right),{ }^{\mathbf{0}} \mathbf{C}$ \\
\hline 1 & 20 & 1 \\
\hline 2 & 20 & 3 \\
\hline 3 & 20 & 5 \\
\hline 4 & 20 & 7 \\
\hline 5 & 40 & 1 \\
\hline 6 & 40 & 3 \\
\hline 7 & 40 & 5 \\
\hline 8 & 40 & 7 \\
\hline 9 & 60 & 1 \\
\hline 10 & 60 & 3 \\
\hline 11 & 60 & 5 \\
\hline 12 & 60 & 7 \\
\hline
\end{tabular}

Process effectiveness was evaluated in terms of the quantity of extracted tannins [15].

\section{Statistical analysis}

Based on experimental data, the equations of tannin extraction were derived, and their coefficients were verified for significance by Student's test and for adequacy - by Fisher's test. All experiments were for performed at least three times. Statistical significance was assessed by Student's-test or ANOVA. Differences between means were considered statistically significant if $\mathrm{p}>0.05$. The figures were created with MicroCal ${ }^{\mathrm{TM}}$ Origin 9.1 software.

\section{Results and discussion}

\section{Obtaining and characteristics of ethanol extracts from physalis leaves}

The analyzed physalis leaves from variety Plovdiv and from the bio-farm were with $8.32 \%$ and $8.79 \%$ moisture level, respectively. The plant materials contained $9.62 \%$ and $10.58 \%$ tannins, respectively for the two genotypes.

The obtained ethanol extracts from physalis leaves were liquids, and their color varied by solvent concentration: yellow-orange (with $30 \%$ ethanol), yellow-brown ( $50 \%$ ethanol), green-brown ( $70 \%$ ethanol), and brown ( $95 \%$ ethanol). 
Figures 1- 4 present the results about the tannin content in the extracts from the two physalis genotypes, according to the scheme of the experiments that have been carried out. The results show that the elevation of temperature from 20 to $60{ }^{\circ} \mathrm{C}$, and the extension of process duration from 1 to $5 \mathrm{~h}$, both increase the content of extracted tannins, independent of ethanol concentration or the origin of the leaves. Extraction for $7 \mathrm{~h}$ resulted in an insignificant increase in the amount of extracted tannins.
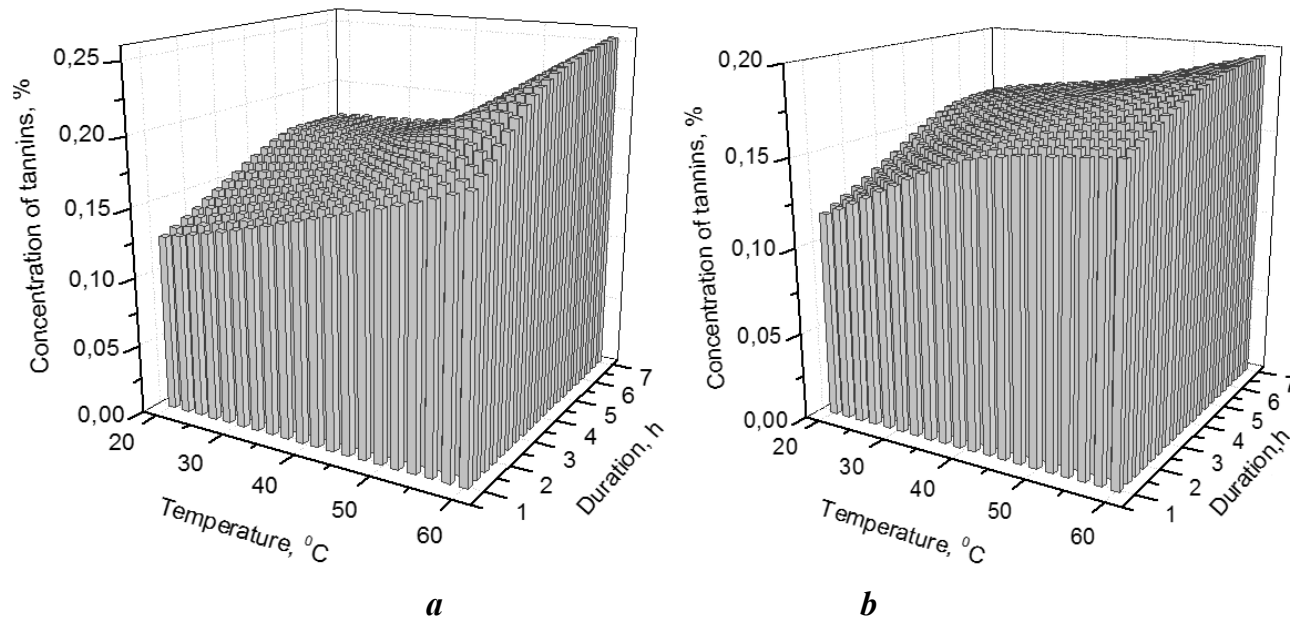

Figure 1. Content of tannins (\%) in extracts from physalis leaves with $30 \%$ ethanol: a - Plovdiv genotype; $b$ - bio-farm genotype.
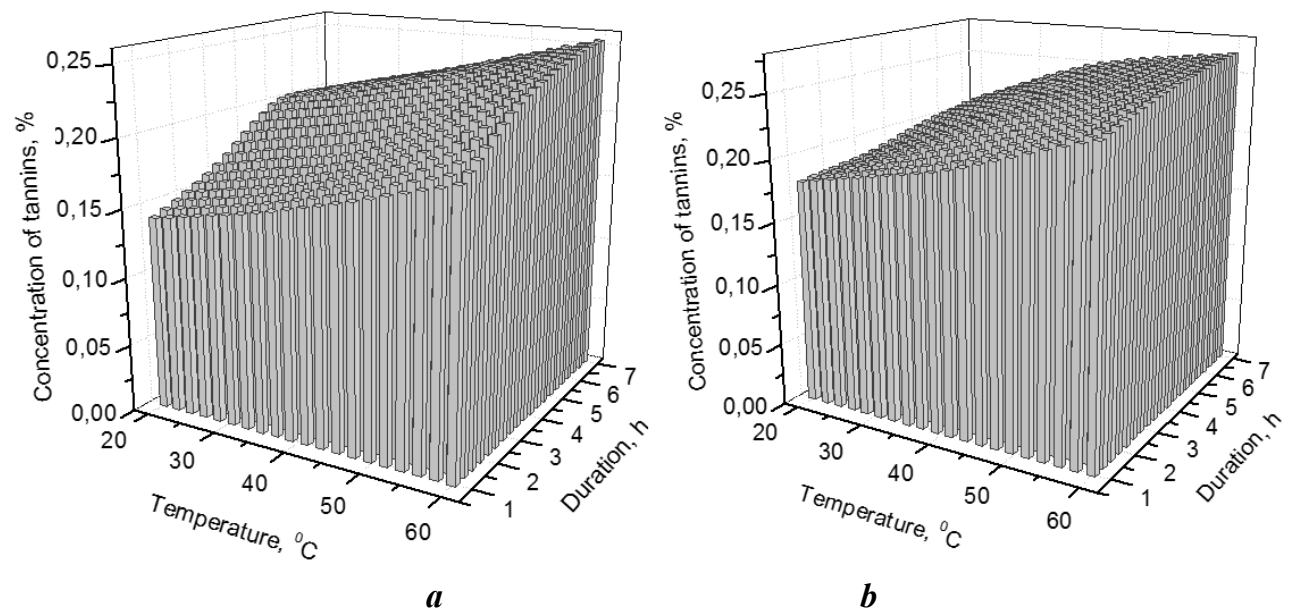

Figure 2. Content of tannins (\%) in extracts from physalis leaves with $50 \%$ ethanol: a - Plovdiv genotype; $b$ - bio-farm genotype. 


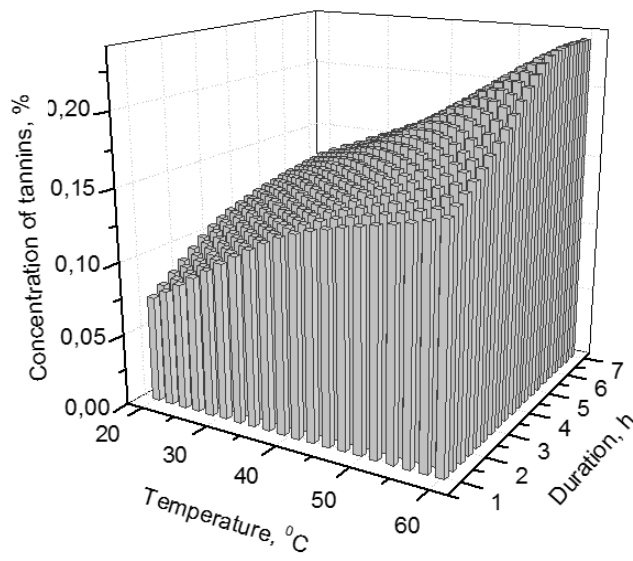

$\boldsymbol{a}$

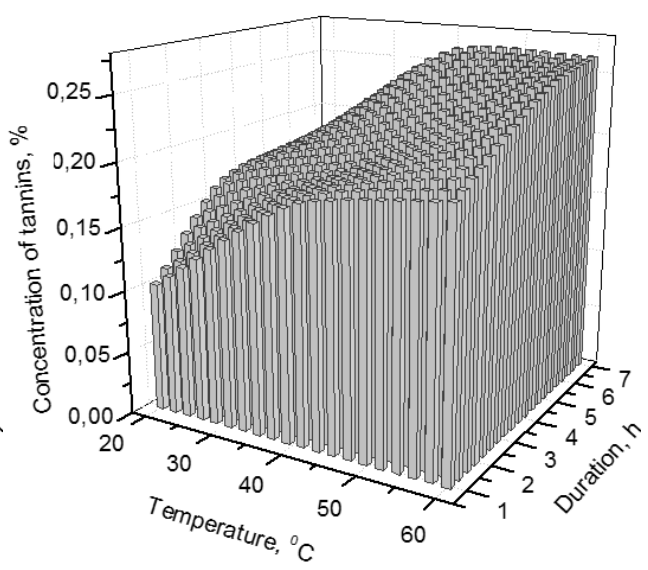

$b$

Figure 3. Content of tannins (\%) in extracts from physalis leaves with $70 \%$ ethanol: a - Plovdiv genotype; $b$ - bio-farm genotype.



$a$

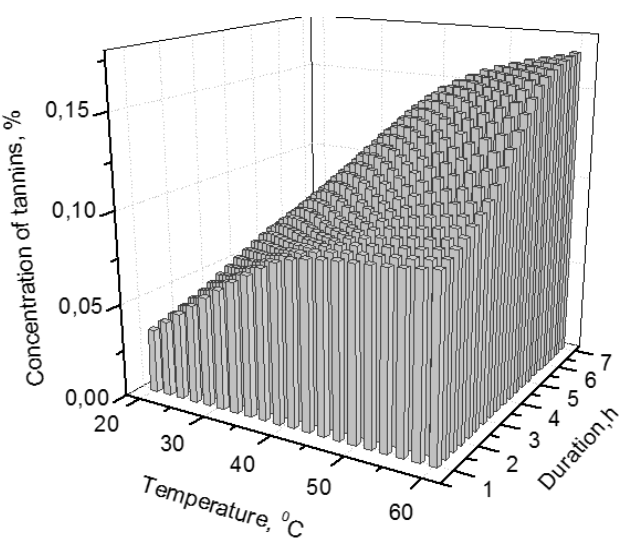

$\boldsymbol{b}$

Figure 4. Content of tannins (\%) in extracts from physalis leaves with $95 \%$ ethanol: a - Plovdiv genotype; $b$ - bio-farm genotype.

Reasonably, the two main factors of the extraction process - duration $\left(\mathrm{x}_{1}\right)$ and temperature $\left(\mathrm{x}_{2}\right)$, had a strong influence on the content of extracted tannins. The relation between tannin content $(\mathrm{y}, \%$. $)$ and process parameters $\left(\mathrm{x}_{1}, \mathrm{~h}\right.$ and $\left.\mathrm{x}_{2},{ }^{\circ} \mathrm{C}\right)$ is confirmed by the obtained equations, which were verified as adequate and with significant coefficients: 


\begin{tabular}{|c|c|}
\hline \multirow{2}{*}{ Solvent } & Equation \\
\hline & Leaves from Plovdiv genotype \\
\hline $30 \%$ ethanol & $y=0.177+0.036 x_{1}+0.023 x_{2}+0.002 x_{1} x_{2}+0.015 x_{1}^{2}-0.006 x_{2}^{2}$ \\
\hline $50 \%$ ethanol & $y=0.190+0.027 x_{1}+0.028 x_{2}-0.003 x_{1} x_{2}+0.005 x_{1}^{2}+0.002 x_{2}^{2}$ \\
\hline $70 \%$ ethanol & $y=0.151+0.047 x_{1}+0.026 x_{2}+0.006 x_{1} x_{2}-0.003 x_{1}^{2}-0.001 x_{2}^{2}$ \\
\hline \multirow[t]{2}{*}{$95 \%$ ethanol } & $y=0.063+0.026 x_{1}+0.019 x_{2}+0.006 x_{1} x_{2}-0.001 x_{1}^{2}-0.005 x_{2}^{2}$ \\
\hline & Leaves from the bio-farm genotype \\
\hline $30 \%$ ethanol & $y=0.167+0.022 x_{1}+0.014 x_{2}-0.004 x_{1} x_{2}-0.006 x_{1}^{2}-0.002 x_{2}^{2}$ \\
\hline $50 \%$ ethanol & $y=0.225+0.032 x_{1}+0.013 x_{2}+0.001 x_{1} x_{2}-0.003 x_{1}^{2}-0.006 x_{2}^{2}$ \\
\hline $70 \%$ ethanol & $y=0.204+0.042 x_{1}+0.029 x_{2}-0.005 x_{1} x_{2}-0.012 x_{1}^{2}-0.006 x_{2}^{2}$ \\
\hline $95 \%$ ethanol & $y=0.088+0.038 x_{1}+0.025 x_{2}+0.011 x_{1} x_{2}-0.008 x_{1}^{2}+0.007 x_{2}^{2}$ \\
\hline
\end{tabular}

The highest concentration of tannins in the extracts was obtained under the following conditions: 5-hour extraction at a temperature of $60^{\circ} \mathrm{C}$, with 30 and $50 \%$ ethanol for the leaves from variety Plovdiv, and with 50 and $70 \%$ ethanol - for the leaves from the bio-farm. The lowest concentration of tannins was obtained with $95 \%$ ethanol, regardless of leaves' origin. The differences in tannin concentration in the extracts obtained with the four ethanol concentrations reflect the significant influence of the solvent, and can be explained with the different selectivity of water-ethanol mixtures used in the extraction of bioactive molecules. The same pattern of the influence of process temperature, duration and ethanol concentration on the content of tannins in liquid extracts has been reported in other studies on essential oilbearing and medicinal plants, such as tobacco [15], mint [16], thyme [17], and rosemary [18].

\section{Polyphenols in physalis leaves and extracts}

The results about the content of phenolic acids and flavonoids in the leaves and extracts of $P$. peruviana are shown in Tables 2 and 3.

Data show that in the leaves and extracts from Plovdiv genotype were identified 12 phenolic acids, and the dominant was rosmarinic acid, followed by salicylic, sinapic and ferulic acids. In the leaves and extracts from the bio-farm genotype were identified 10 phenolic acids, among which dominated protocatechuic acid, followed by chlorogenic, sinapic and vanillic acids. In the leaves and extracts from both genotypes, rutin was the dominant flavonoid, which corresponded to the results obtained by Ertürk et. al. [5].

On a genotype basis, data about flavonoids showed higher levels of the flavon glycoside hesperetin in the leaves of variety Plovdiv, but lower - in the extracts, compared, respectively, to the leaves and extracts from the bio-farm genotype. The concentration of the flavon glycoside myricetin in the leaves and extracts from the bio-farm genotype were characteristically higher.

The content of salicylic, caffeic, p-coumaric, sinapic, ferulic and rosmarinic acids in the samples from Plovdiv genotype was significantly higher than the respective content in the leaves and extracts from the second genotype. Gallic acid, rosmarinic acid, luteolin, kaempherol, and apigenin were not identified in the leaves and extracts from the bio-farm genotype. Despite that, the contents of chlorogenic acid and myricetin were higher than those in the leaves and extracts from variety Plovdiv. 
Table 2

Content of polyphenols in leaves and extracts from Plovdiv genotype (P. peruviana)

\begin{tabular}{|c|c|c|c|c|c|}
\hline \multirow{2}{*}{ Compounds } & \multirow{2}{*}{$\begin{array}{c}\text { Leaves, } \\
\mu \mathrm{g} / \mathrm{g} \text { DW }\end{array}$} & \multicolumn{4}{|c|}{ Ethanol extracts, $\mu \mathrm{g} / \mathrm{mL}$} \\
\hline & & $30 \%$. & $50 \%$. & $70 \%$. & $95 \%$. \\
\hline Gallic acid & -a) & $53.91 \pm 0.51$ & $16.75 \pm 0.15$ & - & - \\
\hline $\begin{array}{l}\text { Protocatechuic } \\
\text { acid }\end{array}$ & $142.77 \pm 1.39$ & - & $39.39 \pm 0.38$ & $7.33 \pm 0.07$ & $2.34 \pm 0.02$ \\
\hline Salicylic acid & $1161.62 \pm 10.54$ & $26.21 \pm 0.25$ & $254.77 \pm 2.50$ & $194.10 \pm 1.90$ & $1.20 \pm 0.01$ \\
\hline $\begin{array}{l}\text { Chlorogenic } \\
\text { acid }\end{array}$ & $193.67 \pm 1.89$ & $17.40 \pm 0.16$ & $19.98 \pm 0.18$ & $31.32 \pm 0.30$ & $1.61 \pm 0.01$ \\
\hline Vanillic acid & $236.47 \pm 2.30$ & $19.92 \pm 0.18$ & $62.85 \pm 0.60$ & $51.27 \pm 0.50$ & $17.08 \pm 0.16$ \\
\hline Caffeic acid & $170.61 \pm 1.69$ & $34.49 \pm 0.33$ & $45.48 \pm 0.44$ & $33.30 \pm 0.30$ & $16.82 \pm 0.15$ \\
\hline Syringic acid & $63.05 \pm 0.62$ & $16.36 \pm 0.15$ & $18.21 \pm 0.17$ & $9.74 \pm 0.09$ & $1.57 \pm 0.01$ \\
\hline $\begin{array}{l}p \text {-Coumaric } \\
\text { acid }\end{array}$ & $665.00 \pm 6.62$ & $119.56 \pm 1.10$ & $136.63 \pm 1.34$ & $125.92 \pm 1.21$ & $58.40 \pm 0.51$ \\
\hline Sinapic acid & $776.05 \pm 7.74$ & $183.59 \pm 1.78$ & $203.10 \pm 2.00$ & $159.07 \pm 1.54$ & $65.01 \pm 0.61$ \\
\hline Ferulic acid & $722.23 \pm 7.20$ & $113.62 \pm 1.10$ & $120.33 \pm 1.19$ & $97.83 \pm 0.93$ & $54.59 \pm 0.50$ \\
\hline Cinnamic acid & $24.63 \pm 0.20$ & $18.79 \pm 0.17$ & $6.79 \pm 0.06$ & $1.36 \pm 0.01$ & $0.52 \pm 0.00$ \\
\hline $\begin{array}{l}\text { Rosmarinic } \\
\text { acid }\end{array}$ & $2316.41 \pm 22.11$ & $322.03 \pm 3.18$ & $508.56 \pm 5.00$ & $529.27 \pm 5.20$ & $238.49 \pm 2.30$ \\
\hline Myricetin & $17.94 \pm 0.17$ & $5.12 \pm 0.04$ & $5.70 \pm 0.05$ & $4.99 \pm 0.04$ & - \\
\hline Hesperetin & $40.85 \pm 0.39$ & $8.77 \pm 0.08$ & $10.01 \pm 0.09$ & $12.77 \pm 0.11$ & $3.22 \pm 0.03$ \\
\hline Quercetin & $6.87 \pm 0.06$ & $2.61 \pm 0.02$ & $2.54 \pm 0.02$ & $2.44 \pm 0.02$ & $2.43 \pm 0.02$ \\
\hline Luteolin & $1.44 \pm 0.01$ & $1.04 \pm 0.01$ & $0.62 \pm 0.00$ & $0.38 \pm 0.00$ & $0.37 \pm 0.00$ \\
\hline Kaempferol & $3.62 \pm 0.03$ & $1.98 \pm 0.18$ & $1.48 \pm 0.01$ & $1.57 \pm 1.50$ & $1.40 \pm 0.01$ \\
\hline Apigenin & $31.09 \pm 0.30$ & $\operatorname{tr}^{\mathrm{b})}$ & $\operatorname{tr}$ & $\operatorname{tr}$ & $\operatorname{tr}$ \\
\hline Rutin & $4996.37 \pm 48.50$ & $738.54 \pm 7.25$ & $999.09 \pm 9.91$ & $1040.12 \pm 10.00$ & $395.68 \pm 3.80$ \\
\hline Hyperoside & $226.96 \pm 2.20$ & - & $34.41 \pm 0.31$ & $36.11 \pm 0.32$ & $15.02 \pm 0.14$ \\
\hline
\end{tabular}

These results reveal the presence of various classes of bioactive polyphenols in the leaves and in the leaf extracts obtained from the two genotypes of physalis grown in Bulgaria. The observed differences in the profile and content distribution of polyphenols are attributed to the impact of plant genotype. The results agreed well with previous findings about polyphenol content in Physalis leaves, for example: total phenolic concentration of 30.9$129.2 \mathrm{mg} / \mathrm{g}$ [19] and $129 \mathrm{mg} / \mathrm{g}$ [26]; total flavonoid concentration of 37.39-226.19 mg/g [6] and $23.036 \mathrm{mg} / \mathrm{g}$ [26]. Studies on the determination of flavonoid and phenolic acid content in different Physalis species has been focused exclusively on the fruits, but current results reveal that leaves' potential of accumulating these secondary metabolites is even higher than that of the fruits [26]. Expectedly, the numerical results for the polyphenol content varied from data found in the scientific literature for other plant materials [22, 23, 24, 25]. The established differences in terms of leaf chemical chemical composition between the present investigation and the reported data may be due to the environmental conditions under which the plants were grown, as well as to the impact of species, origin and extraction technique. 
Table 3

Content of polyphenols in leaves and extracts from bio-farm genotype (P. peruviana)

\begin{tabular}{|l|c|c|c|c|c|}
\hline \multirow{2}{*}{ Compounds } & \multirow{2}{*}{$\begin{array}{c}\text { Leaves, } \\
\boldsymbol{\mu g} / \mathbf{g} \mathbf{D W}\end{array}$} & \multicolumn{4}{|c|}{ Ethanol extracts, $\boldsymbol{\mu g} / \mathbf{m L}$} \\
\cline { 3 - 6 } & $\mathbf{-}^{\mathrm{a})}$ & $\mathbf{3 0 \%}$ & $\mathbf{5 0 \%}$ & $\mathbf{7 0 \%}$ & $\mathbf{9 5 \%}$ \\
\hline Gallic acid & - & - & - & - \\
\hline $\begin{array}{l}\text { Protocatechuic } \\
\text { acid }\end{array}$ & $933.22 \pm 9.28$ & - & - & - & - \\
\hline Salicylic acid & - & $47.94 \pm 0.45$ & $49.45 \pm 0.45$ & $67.64 \pm 0.65$ & $52.26 \pm 0.51$ \\
\hline $\begin{array}{l}\text { Chlorogenic } \\
\text { acid }\end{array}$ & $324.33 \pm 3.20$ & $28.65 \pm 0.26$ & $21.29 \pm 0.20$ & $25.83 \pm 0.24$ & $17.64 \pm 0.16$ \\
\hline Vanillic acid & $248.56 \pm 2.41$ & $3.68 \pm 0.03$ & $68.62 \pm 0.65$ & $67.55 \pm 0.36$ & $40.74 \pm 0.38$ \\
\hline Caffeic acid & $44.90 \pm 0.40$ & $13.01 \pm 0.11$ & $31.60 \pm 0.30$ & $37.75 \pm 0.36$ & $25.16 \pm 0.22$ \\
\hline Syringic acid & $39.25 \pm 0.38$ & $1.13 \pm 0.01$ & $8.47 \pm 0.08$ & $6.01 \pm 0.05$ & $2.60 \pm 0.02$ \\
\hline $\begin{array}{l}p \text {-Coumaric } \\
\text { acid }\end{array}$ & $79.65 \pm 0.75$ & $15.13 \pm 0.104$ & $13.16 \pm 0.11$ & $11.01 \pm 0.10$ & $6.14 \pm .05$ \\
\hline Sinapic acid & $282.59 \pm 2.79$ & $39.06 \pm 0.37$ & $181.69 \pm 1.78$ & $13.18 \pm 0.11$ & $5.55 \pm 0.04$ \\
\hline Ferulic acid & $108.89 \pm 1.00$ & $21.71 \pm 0.20$ & $27.22 \pm 0.25$ & $45.32 \pm 0.43$ & $15.26 \pm 0.14$ \\
\hline Cinnamic acid & $8.45 \pm 0.08$ & $0.84 \pm 0.00$ & $1.77 \pm 0.01$ & $3.29 \pm 0.03$ & $1.94 \pm 0.01$ \\
\hline $\begin{array}{l}\text { Rosmarinic } \\
\text { acid }\end{array}$ & - & - & - & - & - \\
\hline Myricetin & $142.09 \pm 1.40$ & $33.67 \pm 0.31$ & $32.27 \pm 0.30$ & $36.50 \pm 0.33$ & $33.31 \pm 0.30$ \\
\hline Hesperetin & $32.58 \pm 0.30$ & $49.42 \pm 0.47$ & $24.52 \pm 0.21$ & $14.31 \pm 0.12$ & $15.65 \pm 0.14$ \\
\hline Quercetin & $27.17 \pm 0.25$ & $16.32 \pm 0.15$ & - & - & - \\
\hline Luteolin & - & - & - & - & - \\
\hline Kaempferol & - & - & - & - & - \\
\hline Apigenin & - & - & - & - & - \\
\hline Rutin & $2953.44 \pm 2.90$ & $272.04 \pm 2.70$ & $431.82 \pm 4.30$ & $537.00 \pm 5.30$ & $333.79 \pm 3.27$ \\
\hline Hyperoside & $209.11 \pm 0.19$ & $37.28 \pm 0.18$ & $28.77 \pm 0.09$ & $50.53 \pm 0.33$ & $28.48 \pm 0.09$ \\
\hline
\end{tabular}

a) not identified

\section{Triterpenes in physalis leaves and extracts}

The results about the content of triterpenes in the leaves and extracts of $P$. peruviana are shown in Tables 4 and 5.

Table 4

Content of triterpenes in leaves and extracts from Plovdiv genotype (P. peruviana)

\begin{tabular}{|l|c|c|c|c|c|}
\hline \multirow{2}{*}{ Compounds } & \multirow{2}{*}{$\begin{array}{c}\text { Leaves, } \\
\boldsymbol{\mu g} / \mathbf{g} \mathbf{D W}\end{array}$} & \multicolumn{4}{|c|}{ Ethanol extracts, $\boldsymbol{\mu g} / \mathbf{m L}$} \\
\cline { 3 - 6 } & $105.83 \pm 1.00$ & $\mathbf{3 0 \% .}$ & $\mathbf{5 0 \% .}$ & $\mathbf{7 0 \%} \%$ & $\mathbf{9 5 \%}$ \\
\hline Betulin & - & - & $87.24 \pm 0.86$ & $73.98 \pm 0.72$ \\
\hline Betulinic acid & $42.36 \pm 0.40$ & - & - & $67.41 \pm 0.66$ & $35.04 \pm 0.34$ \\
\hline Oleanolic acid & $264.90 \pm 2.60$ & $46.98 \pm 0.45$ & $70.01 \pm 0.69$ & $86.97 \pm 0.85$ & $31.10 \pm 0.30$ \\
\hline Ursolic acid & - & $30.77 \pm 0.29$ & $60.73 \pm 0.60$ & $58.69 \pm 0.57$ & $8.18 \pm 0.07$ \\
\hline
\end{tabular}

a) not identified 
Content of triterpenes in leaves and extracts from bio-farm genotype ( $P$. peruviana)

\begin{tabular}{|l|c|c|c|c|c|}
\hline \multirow{2}{*}{$\begin{array}{l}\text { Compound } \\
\mathbf{s}\end{array}$} & $\begin{array}{c}\text { Leaves, } \\
\boldsymbol{\mu g} / \mathbf{g} \text { DW }\end{array}$ & \multicolumn{4}{|c|}{ Ethanol extracts, $\boldsymbol{\mu g} / \mathbf{m L}$} \\
\hline & $\mathbf{3 0 \%}$ & $\mathbf{5 0 \%}$ & $\mathbf{7 0 \%}$. & $\mathbf{9 5 \%}$ \\
\hline Betulin & $-\mathrm{a})$ & $122.21 \pm 1.2$ & $124.36 \pm 1.21$ & $\begin{array}{c}201.91 \pm 19.9 \\
7\end{array}$ & $\begin{array}{c}394.44 \pm 38.0 \\
0\end{array}$ \\
\hline $\begin{array}{l}\text { Betulinic } \\
\text { acid }\end{array}$ & - & - & - & - & - \\
\hline $\begin{array}{l}\text { Oleanolic } \\
\text { acid }\end{array}$ & $889.83 \pm 8.7$ & $8.15 \pm 0.08$ & $208.93 \pm 19.8$ & $200.87 \pm 19.5$ & $176.52 \pm 1.68$ \\
\hline $\begin{array}{l}\text { Ursolic } \\
\text { acid }\end{array}$ & - & - & - & - & - \\
\hline
\end{tabular}

${ }^{\text {a) }}$ not identified

Three triterpenes were identified in the leaves of Plovdiv genotype, and the dominant were oleanolic acid $(264.9 \mu \mathrm{g} / \mathrm{mg})$ and betulin $(105.83 \mu \mathrm{g} / \mathrm{mg})$. In the second genotype, only oleanolic acid was identified, but in a significantly (nearly four-time) higher concentration $(889.83 \mu \mathrm{g} / \mathrm{mg})$. In total, four triterpenes were identified in the extracts obtained from the leaves of Plovdiv genotype, and there was a clear differentiation between the extracts (30 and $50 \%$ ethanol vs. 70 and $95 \%$ ethanol). In the extracts obtained with the lower solvent concentrations only oleanolic and ursolic acids were identified (total content 77.75 and $130.74 \mu \mathrm{g} / \mathrm{mL}$, respectively). The extracts of the second sub-group were considerably richer in triterpenoids (with a total of 300.31 and $148.30 \mu \mathrm{g} / \mathrm{mL}$, respectively), and the dominant were betulin, betulinic acid and oleanolic acid. In the extracts obtained from the leaves of the bio-farm genotype only two triterpenes were identified - oleanolic acid and betulin, but in higher concentrations (three-to-four times higher). Data from the study suggest that, in terms of triterpenoid content, the more suitable solvents would be 70 and $95 \%$ ethanol.

Our results clearly differentiate between the extracts on a triterpene basis, and the differences reflect the impact of plant genotype and solvent selectivity. With regard to data from previous research on triterpenoid concentration in physalis leaves and leaf extracts, it is even harder to make comparisons, than in the case of polyphenols. To the best of our knowledge the triterpenoid content of physalis leaves, and especially - of genotypes grown in Bulgaria, has not been determined elsewhere. Similar to the observations above, current results about the triterpene content in physalis leaves and ethanol leaf extracts characterize the species as distinctive form other plants, regarding literature data [24, 25]. The differences in the triterpene composition between the present investigation and the reported data may be attributed to environmental conditions, plant material origin and other influencing factors.

\section{Conclusion}

To the best of our knowledge, data achieved by this study provide for the first time the optimal conditions for the extraction procedure of Physalis peruviana L. leaves, as well as information about the content of certain biologically active components in the leaves and in the obtained extracts. These are the first results reported about physalis genotypes grown in 
Bulgaria. The extracts contained phenolic acids, flavonoids and triterpenes, and have the prospective for possible application in different medicinal and cosmetic products, but additional investigations are undoubtedly required.

Acknowledgements. The authors acknowledge the support by the Science Fund of the University of Food Technologies, Plovdiv, Bulgaria (project 04/18-N). The authors are most thankful to Prof. Nikolay Panayotov (Agricultural University, Plovdiv) and to Mr. Miroslav Peshovsky (Versol biofarm, Lik village) for providing the plant material.

\section{References}

1. Sharma N., Bano A., Dhaliwal H., Sharma V. (2015), Perspectives and possibilities of Indian species of genus Physalis (L.) - A comprehensive review, Eur. J. Pharm. Med. Res., 2, pp. 326-353.

2. Puente L., Pinto-Munoz C., Castro E., Cortes M. (2011), Physalis peruviana Linnaeus, the multiple properties of a highly functional fruit: A review, Food Res. Int., 44, pp. 1733-1740.

3. Ramadan M., El-Ghorab A., Ghanem K. (2015), Volatile compounds, antioxidants, and anticancer activities of cape gooseberry fruits (Physalis peruviana L.): an in vitro study, J. Arab Soc. Med. Res., 10, pp. 56-64.

4. Kalugina I., Telegenko L., Kalugina Y., Kyselov S. (2017), The nutritional value of desserts with the addition of Gooseberry family raw materials from the Northern Black Sea Region, Ukrainian Food Journal, 6(3), pp. 459- 69.

5. Ertürk O., Colayvaz M., Can Z., Karaman Ü., Korkmaz K. (2017), Antioxidant, antimicrobial activities and phenolic and chemical contents of Physalis peruviana L. from Trabzon, Turkey, Indian J. Pharm. Educ. Res., 51(3), pp. 213-216.

6. Wu S., Chang S., Lin D., Wang S., Hou F., Ng L. (2009), Supercritical carbon dioxide extract of Physalis peruviana induced cell cycle arrest and apoptosis in human lung cancer H661 cells, Food Chem. Toxicol., 47, pp. 1132-1138.

7. Maobe M.A.G., Gatebe E., Gitu L., Rotich H. (2013), Preliminary phytochemical screening of eight selected medicinal herbs used for the treatment of diabetes, malaria and pneumonia in Kisii region, Southwest Kenya, Eur. J. Appl. Sci., 5(1), pp. 1-6.

8. Cirigliano A., Colamarino I., Mareggiani G., Bado S. (2008), Biological effects of Physalis peruviana L. (Solanaceae) crude extracts and its major withanolides on Certitis capitate Wiedemann (Diptera: Tephritidae), Bol. San. Veg. Plagas, 34, pp. 509-515.

9. Zhang Y., Deng G., Xu X., Wu S., Li S., Li H. (2013), Chemical components and bioactivities of cape gooseberry (Physalis peruviana), Int. J. Food Nutr. Saf., 3(1), pp. $15-24$.

10. Chopra R.N., Nayar S.L., Chopra I.C. (1986), Glossary of Indian Medicinal Plants. Council of Scientific and Industrial Research, New Delhi, India.

11. Panayotov N. (2009), Plovdiv - the first Bulgarian variety of physalis (Physalis peruviana L.), Agr. Sci., 1(1), pp. 9-12 (in Bulgarian).

12. Russian Pharmacopoeia, $11^{\text {th }}$ edition (1990), Medicina, Moscow (in Russian).

13. Marchev A., Georgiev V., Badjakov I., Kondakova V., Nikolova M., Pavlov A. (2011), Triterpenes production by rhizogenic callus of Salvia scabiosifolia Lam. obtained via 


\section{— Food Technology ——}

Agrobacterium rhizogenes mediated genetic transformation, Biotechnol. Biotechnol. Equip., 25, pp. 30-33.

14. Marchev A., Georgiev V., Ivanov I., Badjakov I., Pavlov A. (2011), Two-phase temporary immersion system for Agrobacterium rhizogenes genetic transformation of sage (Salvia tomentosa Mill.), Biotechnol. Lett., 33, pp. 1873-1878.

15. Popova V. (2015), Obtaining and analysis of aromatic extraction products for expanding the usability of tobacco (Nicotiana tabacum L.), DSc Dissertation, University of Food Technologies, Plovdiv, Bulgaria (in Bulgarian).

16. Balinova-Cvetkova A., Stojanova A. (1999), Production of plant extracts for cosmetic applications. Part 2. Peppermint (Mentha piperita L.), Pol. J. Cosmetol., 2(1), pp. $57-$ 60.

17. Damianova S., Tasheva S., Stoyanova A., Damianov D. (2008), Investigation of extracts from thyme (Thymus vulgaris L.) for application in cosmetics, J. Essent. Oil Bear. Pl., 11(5), pp. 443-450.

18. Damianova S., Tasheva S., Stoyanova A., Damianov D. (2010), Investigation of extracts from rosemary (Rosmarinus officinalis L.) for application in cosmetics, J. Essent. Oil Bear. Pl., 13(1), pp. 1-11.

19. Wang S.Y., Lin H.S. (2000), Antioxidant activity in fruits and leaves of blackberry, raspberry, and strawberry varies with cultivar and developmental stage, J. Agric. Food Chem., 48, pp. 140-146.

20. Grębosz-Krawczyk, M. (2018), The Impact of Nostalgia on the Brand Equity in Economy with Post-Communist Background.Economics and Sociology, 11(2), pp. 216228, DOI:10.14254/2071-789X.2018/11-2/15

21. Cuvelier M.E., Richard H., Berset C. (1996), Antioxidant and phenolic composition of pilot-plant and commercial extracts of sage and rosemary, J. Am. Oil Chem. Soc., 73, pp. 645.

22. Baydar H., Özkan G., Erbaş S., Altındal D. (2009), Yield, chemical composition and antioxidant properties of extracts and essential oils of sage and rosemary depending on seasonal variations, Acta Horticulturae, 826, pp.383-389.

23. Pop A.-M., Tofană M., Socaci S., Nagy M., Fărcaş A., Borş M., Salanţă L., Feier D., Vârva L. (2014), Comparative study regarding the chemical composition of essential oils of some Salvia species, Hop and Medicinal Plants, 42(1-2), pp.79-91.

24. Razboršek M., Voneina D., Doleček V., Vončina E. (2007), Determination of major phenolic acids, phenolic diterpenes and triterpenes in rosemary (Rosmarinus officinalis L.) by gas chromatography and mass spectrometry, Acta Chimica Slovenica, 54, pp. 6067.

25. Jäger S., Trojan H., Kopp T., Laszczyk M., Scheffler A. (2009), Pentacyclic triterpene distribution in various plants - rich sources for a new group of multipotent plant extracts, Molecules, 14, pp. 2016-2031.

26. Medina-Medrano J. R., Almaraz-Abarca N., González-Elizondo M. S., Uribe-Soto J. N., González-Valdez L. S., Herrera-Arrieta Y. (2015), Phenolic constituents and antioxidant properties of five wild species of Physalis (Solanaceae), Botanical studies, 56(1), pp. 24. 